\title{
交献上より見たる中国癩病史の一端
}

因立台湾大学赖份和

\section{ON A PART OF HISTORY OF LEPROSY IN CHINA APPEARED IN LITERATURES}

Prof. Shang-Ho Rai M. D.

(National University of Formosa)

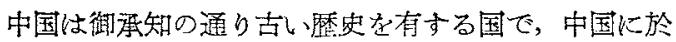
ける䅋病も亦同時歷皮は樑く始好て医学的記还の出来

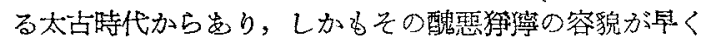
から社会的に種々の方面に利用されて居る事は中国湍病 史の一特色でありふしよう。

私は此度北京中央図書館の遷台及び各種珍古書籍の公 私人化依りて移大した衔落て，多くの経更漠方医菜書籍

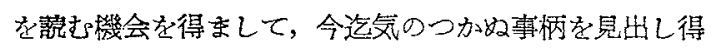
ましたので姆化数例を挙げて見末しよう。

\section{1 癞発病と年齡との関係}

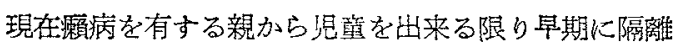
すれ温童は多くの場合発病せずに止むと，父感染時期 の多くは奻少時代に多いと云う事を云われて居るが， 1773年清乾隆時代顧世澄の著したる䈍医大全第二十八巻 大麻風門作「風之始由各有不同 有活年而発者 有 14 ～15藏而登者 有 $4 \sim 5$ 藏而発者」。

所感有殊 其壮年而発者 因不能節愁致寉腎元精夜枯 调 㬺理不密 易感寒湿之邪。14～15藏而発者 先大不

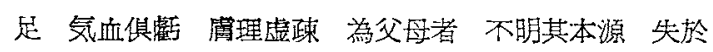
護育 致感寒湿之邪 入於筋骨 其登之速 其遍之易 非讷年可比 百不能全四五 何也 因其筋骨未堅 肌肉

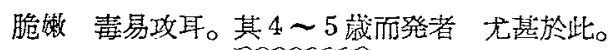

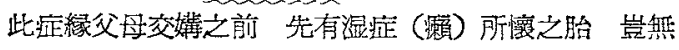
是疾 既生之後 日積月累 遍澄周身後感風邪 湿遇 風 而化熱 菣蒸血眼肌肉遂癹此症。

其の所論は近代の科学飞完全合致して居ると云わ奴 が，約 200 年前の清乾隆時代から 14〜15 藏のbのは壮 年よりも容易に，4～5歳の者は. 14～15葴のものよりる より容易に感染する事及び胎盤感染の可能性多るととを 顧世澄か注唱して居たすのでるる。

\section{二 類瀨体翼之記迹}

西曆 270 年頃晋皇甫䛦著作の黄帝鋮众甲乙経第入巻陽
受病発風之項目に「黄帝閣日，人之善病風濯々汗出者何 以候之。岐伯日 肉不㹂㬺理蹯者善風也, 帝曰何以候

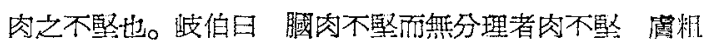

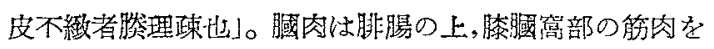

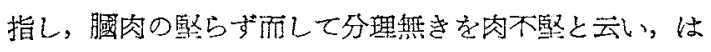
だのきめの緻密を欠くるを燃理眯と云う。斯る者は気を 泄漏し容易に出汗する，依つて風病炕篗り易いと云う。 鋮炎甲乙経はより古しの䇥枢「五変第四十六」の説を分 り易く引用したのである。

黄帝岐伯は中国太古の医薬界比最貢献の出つ大君臣 で後世の作家克く問答式の医畫に利用する。本処の黄帝 問, 岐伯答もとの例であつて，本人であると否は問題で ない。

\section{三攋醜形容の利用}

形容醜变の潞病は，今の人の㟲覀のみならず，古人る

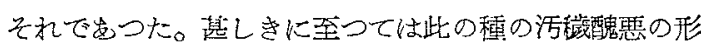

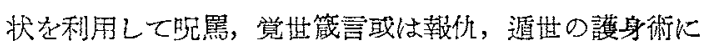
利用して来たのでめる。

1. 哠琟に於ての利用

春秋左伝に「親逐而君，爾父為厲」との訽がある。 春秋時代衛，棌荡の父棌林父の国君を逐ら大事は西曆約 560 年前の铢である。

2. 護身化於ての利用

甲，復 仇

東周列国時代 趋 襄子 与韓国槐国聯合，而減智伯

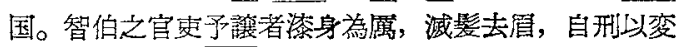
其容, 為乞人而往气, 其妻不識曰, 状琓不似吾夫, 其

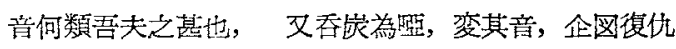
（戦国策串記）此の事は西曆約 453 年前の事である。 乙, 遁 世.

$A$, 践国策比范脽説秦王(秦昭王, 前 255 年)の一交文 り，その一節「臣今日旁之於前 明日快誅於後, 然臣不 敢避地，大干信能行臣之㝘, 死不足為臣患, 亡足以為臣 


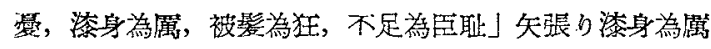

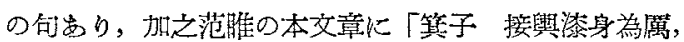
被影為狂」の呵がある。筫子は紀元前 1154 年股の時代 の紂王の叔父で，接罢仕孔子同時代，楚の賢人陸通の 別号でる。

$\mathrm{B}$ ，華陽国誌儿「漢光武帝時，公孫述㘹反 知費胎之

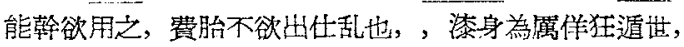
公孫述破後，方出合浦之守」。公孫述の叛反酒等 23 年 頃の害奇る。

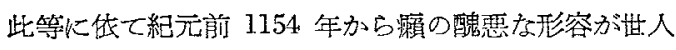
の泊悪を幸比護身に利用した例である。

3. 党世筬言比於ての利用

甲，西䅨 368 年前辇子の著作華南真経们属与西施」 の句者り，日く「可乎可，不可乎不可，道行之而成，物 譄之而然，然於然 覀乎不然 不然於不然 物固有所然

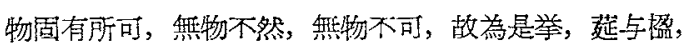
属与西施，恢脃情怪，道其一」。荘子の性格を以て言学 ば正に如是でめる，普通の言い方を以てすれば，其の意 味は㺃是人の極醜，西施是人の極美でする。極酥之極美 は，極より極に至る其の差の遠からずの窝意で，仏経の 色則是空，筀則是色，即ち之れで萃ろら。

乙，西暦240年前秦 韓非の著作韩韭子, 或俚西暦 107

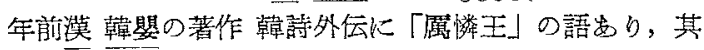
の意，厲は極めて慘酷の病にして沿癒易からざるも，直

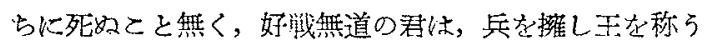
るも，遠からず正化劫殺を受け死亡するものである。故

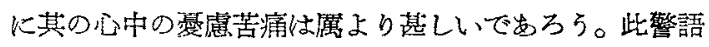
は戦国時代に盛行した言葉であつた。

以上原著諸書に在りては各特殊の用意有るでめろう。

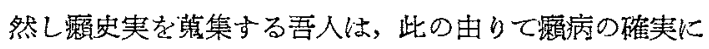
当時の社会に存在せる反証となり，且その䁛悪なる形容 は早くから種々の方面に利用立られて居大事か汾かる。

4. 伯牛の疾

孔子の弟子，伯牛の疾は非粯に非らずや，その理由に

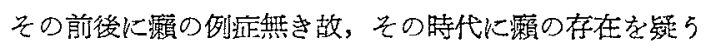
と或者は梅毒心韭らずやと説まるも，孔子の出生恓西攵 前 551 年にして 12 賢人の一人であつた。伯牛の死は热 らく孔子䀠化名を成しての紀元前 500 年頃であるう。 されば上記紀元前のみの記録を見るに 1154，560，453， $368 ， 240 ， 170$ と続出し更に精查すれば交献がもつと出 る事が予想される。上記諸例化徴しても西膯 500 年前中 国に斯の病気の多つた事は何等珍らしい事でない。

又梅毒の中国伝来は 16 世紀 (明)なる焉は既に知ら れて居るが実際素問，霊枢，病源候論，千金方等心梅毒 に類似な徵状の記载を見当らず顆に相遠ないと惟ら。

（頼尚和搏士は，残念ながら学会え出席できなかつたの ですが，ととにとの講演要旨のみを揭げます。) 